\title{
STRATEGI IMPLEMENTASI UNTUK MENGENDALIKAN KONVERSI LAHAN SAWAH DI KOTA SUKABUMI
}

\author{
The Implementation Strategy to Control Paddy Land Conversion In \\ Sukabumi City
}

\section{Ari Wijayanti ${ }^{1}$, Khursatul Munibah $^{2}$, Eka Intan Kumala Putri ${ }^{3}$}

Diterima: 6 Agustus 2016 Disetujui: 16 Oktober 2016

\begin{abstract}
Abstrak: Konversi lahan sawah di Kota Sukabumi berada pada kondisi yang mengkhawatirkan dimana pengurangan lahan tiap tahunnya mencapai 6.06 ha, padahal produktivitasnya tinggi mencapai 6.7 ton/ha. Tujuan dari penelitian ini adalah untuk menganalisis konversi lahan sawah menjadi lahan non sawah di Kota Sukabumi dan persepsi petani mengenai kesediaan untuk mengikuti Perlindungan Lahan Pertanian Pangan Berkelanjutan (PLP2B). Penelitian ini menggunakan analisis overlay untuk mengetahui konversi lahan sawah pada tahun 2010, 2012 dan 2015dan A' WOT digunakan untuk merumuskan strategi unruk mengimplementasikan PLP2B. Hasil analisis menunjukkan bahwa lahan sawah terkonversi seluas 181.94 ha. Strategi untuk mengimplementasikan PLP2B adalah dengan meningkatkan produktivitas, membangun kerjasama dengan pihak swasta dan penguatan kelembagaan kelompok tani.
\end{abstract}

Kata kunci: Konversi., lahan sawah, strategi implementasi, PLP2B

\begin{abstract}
Paddy land conversion in Sukabumi City is worrying whereas its rate is 6,06 ha annually, while its production is very high that reaches 6.7 ton/ha. The aims of this study are to analyze the total paddy land that had been converted into other uses as well as to formulate strategies to implement this program. The method used are by using overlay land use map year 2010, 2012 and 2015 and combination AHP-SWOT The results show that paddy land that had been converted into other uses as many as $181.94 \mathrm{ha}$. The main strategies to implement this program are by increasing productivity, developing cooperation between private sector and farmer group, and strengthening its institution.
\end{abstract}

Keywords: Paddy field, conversion, farmer's perception, PLP2B.

\footnotetext{
${ }^{1}$ Program Studi Ilmu Perencanaan Pembangunan Wilayah dan Perdesaan, Institut Pertanian Bogor

${ }^{2}$ Program Studi Ilmu Ekonomi Pertanian dan Sumberdaya, Departemen Ekonomi Sumberdaya dan Lingkungan, Institut Pertanian Bogor

${ }^{3}$ Program Studi Ilmu Perencanaan Wilayah, Departemen Ilmu Tanah dan Sumberdaya Lahan, Institut Pertanian Bogor
} 


\section{PENDAHULUAN}

Padi dapat tumbuh di 114 negara di dunia dan menjadi makanan pokok hampir sebagian penduduk dunia (Katayama N, et.al, 2015). Di antara komoditas pangan, padi/ beras merupakan bahan pangan pokok bagi penduduk Indonesia. Pertumbuhan penduduk yang jumlahnya semakin meningkat dari tahun ke tahun mengakibatkan bertambahnya kebutuhan - kebutuhan pokok penduduk, salah satunya adalah kebutuhan akan pangan. Kebutuhan pangan bertambah, sementara luas lahan pertanian tetap bahkan jumlahnya menurun karena terkonversi menjadi lahan non-pertanian. Periode 1992-2002, laju konversi lahan pertanian menjadi non pertanian sebesar $110.000 \mathrm{ha} /$ tahun dan meningkat menjadi 145.000 ha/tahun pada tahun 2002-2006, dan pada tahun 2007-2010 menjadi $200.000 \mathrm{ha} /$ tahun (Khudori, 2012). Ini mencakup konversi ke penggunaan non-pertanian maupun ke penggunaan lahan untuk usaha tani non-sawah..

Sebagai sumberdaya alam, lahan merupakan wadah dan faktor produksi strategis bagi kegiatan pembangunan untuk meningkatkan kesejahteraan manusia. Perubahan pola penggunaan lahan pada dasarnya bersifat dinamis mengikuti perkembangan penduduk dan pola pembangunan wilayah (Utomo, 1992). Sumaryanto (1994) memaparkan bahwa jika suatu lokasi terjadi konversi lahan pertanian maka lahan-lahan di sekitarnya akan terkonversi juga dan sifatnya cenderung progresif. Laju konversi lahan sawah masih cukup besar bahkan merambah ke lahan sawah irigasi teknis yang sangat potensial untuk produksi padi sawah (Irawan, 2008)

Lahan pertanian pangan yang potensial dan telah sesuai kriteria untuk dilindungi, perlu ditetapkan dan dimasukkan dalam Peraturan Daerah dan merupakan bagian integral dengan Rencana Tata Ruang Wilayah yang rinci di Kabupaten/Kota. Produk turunan dari UU No.41 tahun 2009 telah banyak dibuat untuk mendukung implementasi pelaksanaan kebijakan Perlindungan Lahan Pertanian Pangan Berkelanjutan (PLP2B). Gubernur Jawa Barat dengan tanggap juga telah mengeluarkan Perda Nomor 27 tahun 2010 mengenai Perlindungan Lahan Pertanian Pangan Berkelanjutan yang menerangkan bahwa Jawa Barat sebagai lumbung pangan nasional akan melindungi lahan pertanian pangannya untuk menjaga kedaulatan pangan. Di Kota Sukabumi telah dilakukan kajian PLP2B yang merekomendasikan wilayah PLP2B dan LCP2B sesuai dengan beberapa parameter. Sementara Peraturan Daerah terkait sedang dalam penyusunan. Agar kebijakan PLP2B dapat diimplementasikan maka diperlukan strategi penyusunan yang berdasar pada aktor yang terkait dengan kebijakan tersebut, yaitu petani sebagai masyarakat desa, pemerintah, dan regulasi itu sendiri.

Berdasarkan uraian di atas, maka tujuan yang ingin dicapai pada penelitian ini adalah menganalisis konversi lahan pertanian (sawah) ke lahan non-pertanian di Kota Sukabumi tahun 2010, 2012 dan 2015, serta merumuskan strategi implementasi kebijakan PLP2B di Kota Sukabumi.

\section{METODE}

Penelitian ini dilaksanakan di Kota Sukabumi, Propinsi Jawa Barat. Kota Sukabumi mempunyai produktivitas tertinggi di Propinsi Jawa Barat pada tahun 2012 namun mempunyai laju konversi lahan yang besar. Kecamatan yang dipilih berdasarkan kajian dari Dinas Pertanian, Perikanan dan Ketahanan Pangan Kota Sukabumi bersama dengan Institut Pertanian Bogor, yaitu di Kecamatan Baros, Kecamatan Cibeureum, Kecamatan Gunungpuyuh, dan Kecamatan Lembursitu sebagai bahan penetapan calon lokasi dalam Perda PLP2B di Kota Sukabumi (Gambar 1).

Data yang dikumpulkan berupa data primer dan data sekunder. Teknik pengambilan sample menggunakan metode purposive sampling. Responden merumuskan 
strategi berasal dari dari Dinas Pertanian, Perikanan dan Ketahanan Pangan 1 orang, Dinas PSDA 1 orang, Bappeda 1 orang, Badan Pertanahan Daerah 1 orang, Sekretarias Daerah 2 orang, Badan Penanaman Modal dan Pelayanan Terpadu 1 orang dan tokoh masyarakat 1 orang sehingga terdapat responden sejumlah 8 orang.

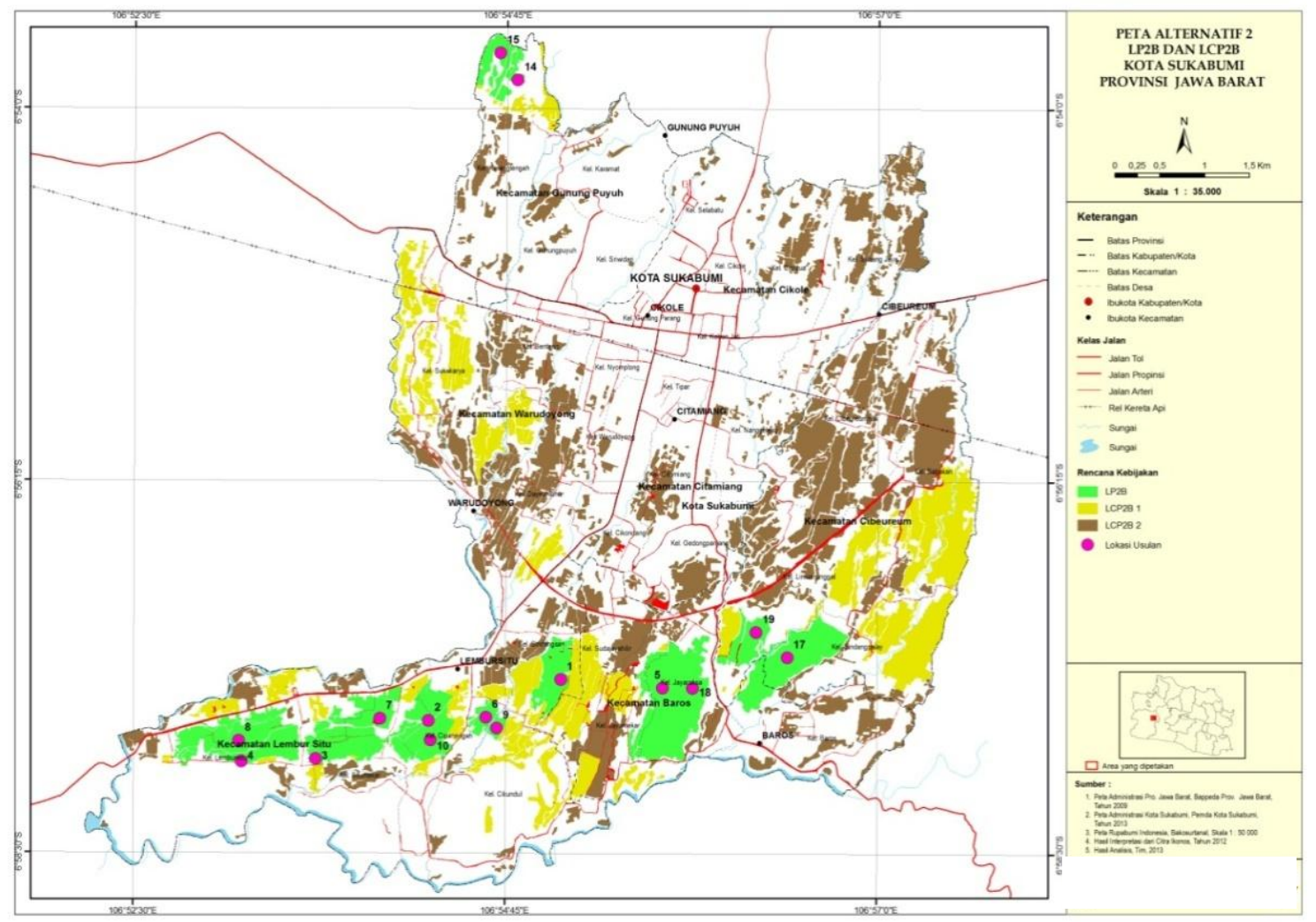

Gambar 1. Peta Hasil Kajian Calon LP2B dan LCP2B di Kota Sukabumi

Evaluasi pemanfaatan ruang aktual (existing) yang meliputi penggunaan lahan (land use) dan penutupan lahan (land cover) diperlukan untuk menggambarkan kondisi fisik wilayah secara aktual. (Rustiadi dkk, 2007). Analisis keruangan yang digunakan pada penelitian ini adalah "overlay." Analisis ini digunakan untuk mengetahui hasil interaksi atau gabungan dari beberapa peta.

Peta penggunaan lahan yang dipilih ialah peta lahan sawah tahun 2010 dan 2012 yang bersumber dari PSP3 dan Dinas Pertanian Kota Sukabumi dan pada tahun 2015 peta sawah hasil digitasi dengan google earth. Peta tersebut akan dioverlaykan secara berurut sehingga terlihat perubahan penggunaan lahannya.

Penggunaan analisis centroid digunakan untuk melihat arah kecenderungan pergeseran perubahan konversi lahan sawah dari area terluar ke arah pusat.

Arahan strategi pengendalian alih fungsi lahan dilakukan melalui pendekatan analisis A'WOT yang merupakan kombinasi dari metode AHP (Analytical Hierarchy Process) dan SWOT (Strengths, Weaknesses, Opportunities, Threats) yang lazim digunakan dalam menyusun strategi kebijakan. AHP berfungsi untuk memberikan bobot atau skor terhadap komponen-komponen SWOT. Metode A'WOT yang diterapkan dalam penelitian ini untuk menentukan pembobotan dalam analisis SWOT. Tujuannya 
adalah untuk mengurangi subjektifitas penilaian terhadap faktor-faktor internal dan eksternal, baik menyangkut kekuatan, kelemahan, peluang maupun ancaman.

Tahapan-tahapan dalam analisis A'WOT meliputi: 1) Penentuan dan pengelompokkan setiap faktor-faktor SWOT, 2) Mengaplikasikan AHP untuk menentukan bobot setiap kelompok dan 3) Mengaplikasikan kembali AHP untuk untuk menentukan prioritas semua faktor dalam semua kelompok SWOT (Ozmen et al. 2013). Untuk dapat merumuskan strategi pengendalian alih fungsi lahan di Kota Sukabumi diawali dengan mengidentifikasi faktor-faktor yang berpengaruh baik faktor internal (kekuatan, kelemahan) maupun eksternal (peluang, ancaman). Faktor-faktor internal dan eksternal yang teridentifikasi merupakan faktor yang mempengaruhi pengendalian alih fungsi lahan di Kota Sukabumi, yang diperoleh dari hasil studi literatur (desk study), hasil analisis sebelumnya dan diskusi dengan para ahli.

Struktur dalam menentukan prioritas strategi pengendalian alih fungsi lahan yang optimal di Kota Sukabumi disajikan pada Gambar di bawah ini

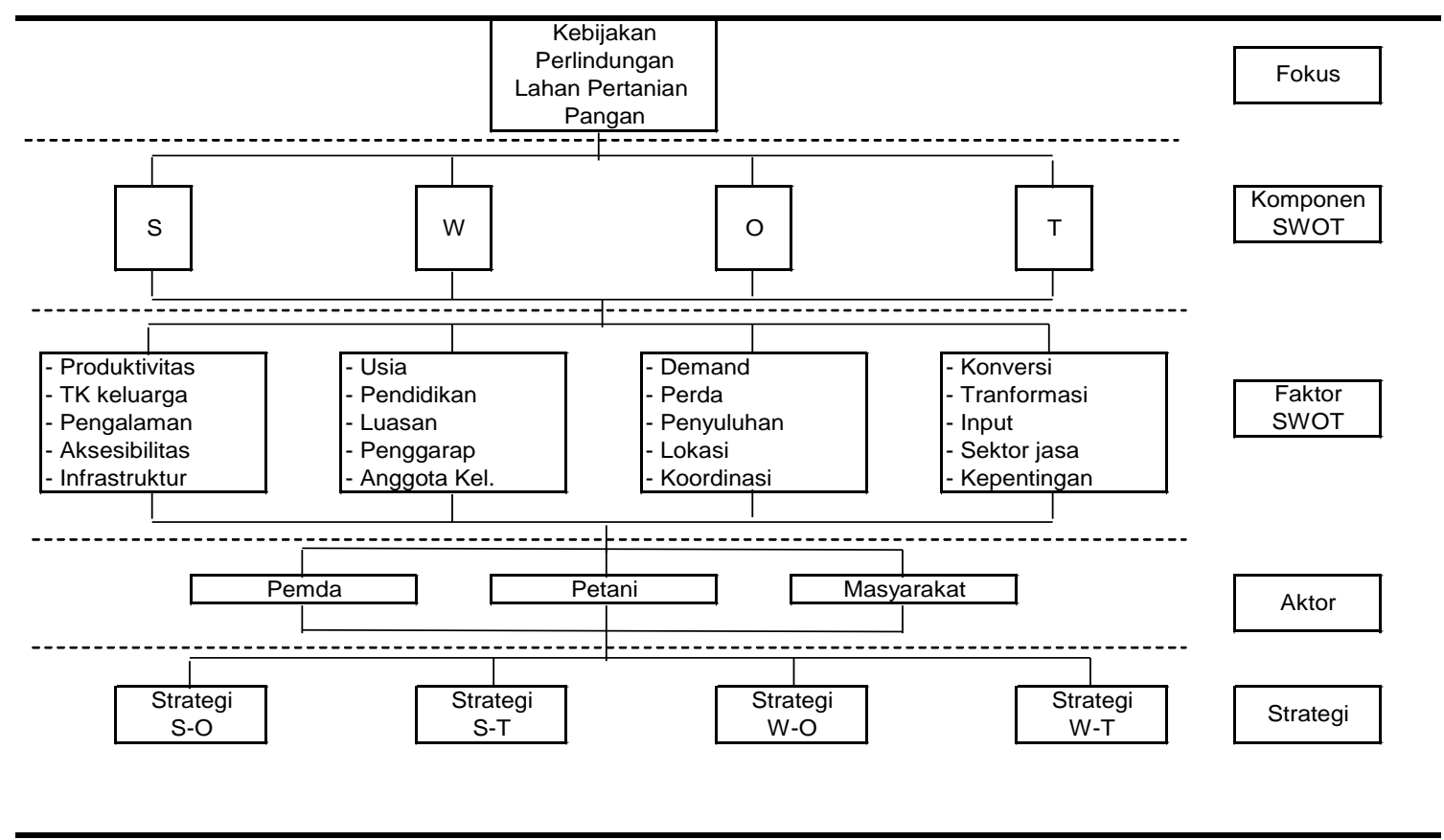

Gambar 2. Struktur AHP Penentuan Prioritas Kebijakan Perlindungan Lahan Sawah Irigasi

\section{HASIL DAN PEMBAHASAN}

\section{Konversi Lahan Pertanian (Sawah) ke Lahan Non-Pertanian}

Konversi lahan pertanian (sawah) ke non pertanian di Kota Sukabumi terus terjadi dan sulit dihindari akibat pertumbuhan ekonomi sehingga mendorong terjadi peningkatan kebutuhan lahan untuk kegiatan-kegiatan non pertanian. Data konversi lahan pertanian (sawah) dapat diperoleh dari Badan Pertanahan Nasional (BPN) dan Badan Pusat Statistik (BPS). Data konversi lahan pertanian (sawah) dari BPN diperoleh dengan memanfaatkan data berupa Izin Perubahan Penggunaan Tanah (IPPT), izin lokasi rencana perolehan dan atau penggunaan tanah dan surat pemberitahuan/klarifikasi rencana perolehan dan atau penggunaan tanah. Data konversi lahan pertanian (sawah) dari BPS diperoleh dari perubahan luas lahan sawah setiap tahunnya dan dari data konversi lahan sawah yang dikumpulkan dari hasil monitoring dan pencatatan di lapang melalui sensus. 
Data luas konversi lahan pertanian ke non pertanian yang diterbitkan oleh instansi berbeda satu dengan lainnya. Perbedaan ini bisa disebabkan karena metode pengukuran yang digunakan berbeda. Menurut Irawan (2005), perbedaan data konversi lahan oleh masing-masing instansi disebabkan oleh perbedaan organization interest dan metode pengukuran yang digunakan. Data luas konversi lahan yang digunakan dalam penelitian ini menggunakan peta tahun 2010. 2012 dan tahun 2015.

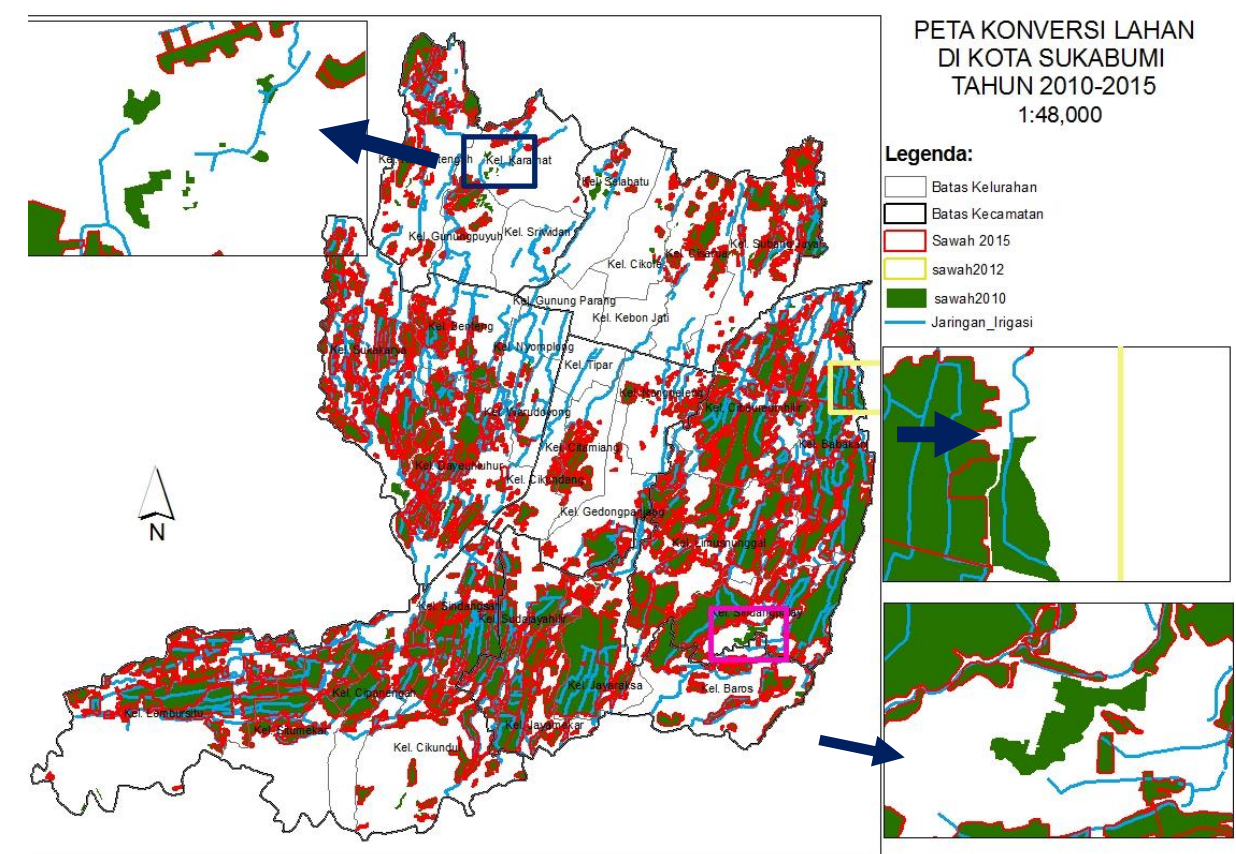

Gambar 3. Peta Konversi Lahan Sawah di Kota Sukabumi Tahun 2010 - 2015

Pada tahun 2010 luas sawah di Kota Sukabumi seluas 1.638,06 Ha. Pada tahun 2012 luas sawah di Kota Sukabumi sebesar 1.578,56 hektar dan pada tahun 2015 menjadi 1.456,32 hektar. Terjadi konversi lahan sebesar 181,74 hektar dalam kurun waktu lima tahun. Berikut sebaran luas penggunaan lahan sawah tahun 2010, 2012 dan 2015, serta besar perubahannya.

Tabel 1. Perubahan Luas Lahan Sawah Per Kecamatan di Kota Sukabumi Tahun 2010-2015

\begin{tabular}{|c|c|c|c|c|c|c|c|}
\hline \multirow[b]{2}{*}{ Kecamatan } & \multicolumn{3}{|c|}{ Penggunaan Lahan Sawah (Ha) } & \multicolumn{4}{|c|}{ Perubahan Luas Lahan (Ha) } \\
\hline & $\begin{array}{l}\text { Tahun } \\
2010\end{array}$ & $\begin{array}{l}\text { Tahun } \\
2012\end{array}$ & $\begin{array}{l}\text { Tahun } \\
2015\end{array}$ & $\begin{array}{l}\text { Tahun } \\
2012\end{array}$ & $\%$ & $\begin{array}{l}\text { Tahun } \\
2015\end{array}$ & $\%$ \\
\hline Baros & 259.7 & 256.3 & 192.29 & 3.4 & $1.31 \%$ & 64.01 & $24.97 \%$ \\
\hline Cibeurueum & 508.2 & 490.1 & 476.93 & 18.1 & $3.56 \%$ & 13.17 & $2.69 \%$ \\
\hline Cikole & 102 & 90.38 & 60.45 & 11.62 & $11.39 \%$ & 29.93 & $33.12 \%$ \\
\hline Citamiang & 67.79 & 65.8 & 65.8 & 1.99 & $2.94 \%$ & 0 & $0.00 \%$ \\
\hline Gunungpuyuh & 81.41 & 76.63 & 69.78 & 4.78 & $5.87 \%$ & 6.85 & $8.94 \%$ \\
\hline Lembursitu & 364.81 & 356.9 & 351.8 & 7.91 & $2.17 \%$ & 5.1 & $1.43 \%$ \\
\hline Warudoyong & 254.15 & 242.45 & 239.27 & 11.7 & $4.60 \%$ & 3.18 & $1.31 \%$ \\
\hline Jumlah & 1638.06 & 1578.56 & 1456.32 & 59.5 & $3.63 \%$ & 122.24 & $7.74 \%$ \\
\hline
\end{tabular}

Sumber: Hasil Overlay 
Kecamatan Cikole merupakan kecamatan dengan perubahan penggunaan lahan sawah terluas dibandingkan dengan kecamatan lainnya. Hal ini wajar karena Kecamatan Cikole merupakan pusat kota Sukabumi sehingga perkembangan lahan terbangun relatif lebih cepat dibanding dengan kecamatan lainnya. Beberapa Kantor Pemerintahan pada tahun 2015 telah dibangun atau dipindahkan ke Kecamatan Cibeureum dan Baros seperti Bappeda, Badan Kepegawaian Daerah, dan terminal dengan maksud untuk pemerataan pembangunan kecamatan.

Di Kecamatan Lembursitu dibangun Dinas Pertanian, dan Dinas Perhubungan. Dengan adanya perpindahan beberapa kantor pemerintahan ke kecamatan tersebut maka di sekitar kantor juga mulai terjadi perubahan fungsi lahan menjadi pertokoan atau perumahan. Di Kecamatan Gunungpuyuh sebelah utara (Kelurahan Karang Tengah) akan dilewati jalan tol Bogor - Sukabumi, sehingga luas perubahan lahan sawah akan semakin meluas jika jalan tol tersebut telah terbangun.

Potensi terjadinya konversi lahan bisa terjadi dikarenakan kebutuhan dan besarnya ketersediaan existing. Kecenderungan konversi suatu lahan menjadi lahan terbangun pada suatu kota sangat besar. Oleh karena itu, potensi transisi melalui hasil analisis pada Gambar menjadi informasi berharga dalam pengelolaan lahan pertanian ke depan terutama perhatian terhadap subjek agraria yang mengelola sumber-sumber agraria tersebut. Oleh karena itu, jika kepemilikan/ penguasaan lahan oleh petani yang menggantungkan hidup pada pertanian, maka potensi tersebut akan bertambah kecil lagi untuk terkonversi.

\section{Kebijakan Lahan}

Pencegahan dan pengendalian kegiatan konversi lahan pertanian, sejauh ini pemerintah Kota Sukabumi lebih terfokus pada pendekatan hukum yaitu dengan membuat peraturan dan perundang-undangan yang bersifat melarang konversi lahan pertanian, khususnya lahan sawah beririgasi teknis. Dalam pelaksanaannya terdapat dua jenis acuan instrumen hukum yang digunakan yaitu:

a. RTRW yang mengatur lokasi kegiatan pembangunan termasuk lahan pertanian yang dapat dikonversi ke penggunaan di luar pertanian.

b. Peraturan-peraturan yang mengatur prosedur pelaksanaan konversi lahan pertanian. Selama ini sudah cukup banyak peraturan pemerintah yang berkaitan dengan konversi lahan pertanian tersebut.

Walikota mempunyai wewenang memberikan ijin terkait kebijakan lahan saat ini melalui Badan Penanaman Modal dan Pelayanan Terpadu (BPMPT). Dalam proses konversi lahan pertanian 'yang berijin' perlu disepakati oleh tim. Tim ini terdiri dari BPMPT, Badan Pertanahan Daerah, Dinas Pertanian, Dinas Tata Ruang dan Pemerintahan, Biro Hukum-Bappeda, DLAJR, Pol-PP dan Dinas Ketenagakerjaan. Acuan dasar dari perijinan konversi lahan adalah RTRW yang berlaku.

\section{Strategi dalam Mengatasi Alih Fungsi Lahan}

Hasil pembobotan komponen SWOT dan faktor-faktor SWOT menggunakan AHP disajikan di bawah ini.Prioritas strategi dalam mengatasi alih fungsi lahan di Kota Sukabumi ditentukan berdasarkan jumlah bobot. Strategi yang memiliki nilai jumlah bobot terbesar menjadi prioritas utama. Strategi SO1 memiliki jumlah bobot yang paling besar, yaitu 0,616 dan berturut turut WO2, SO2, WT2, WO1, WT1, ST1 dan ST2. Jumlah bobot dan urutan/ranking strategi dalam Mengatasi Alih Fungsi Lahan di Kota Sukabumi disajikan pada tabel di bawah ini 
Arahan kebijakan atau program yang disarankan berdasarkan prioritas strategi di atas, yaitu:

1. Implementasi Perda LP2B jika telah disusun. LP2B akan memotivasi petani dengan pemberian insentif dan disinsentif yang sesuai dengan keinginan petani dan pemerintah daerah.

2. Sosialisasi kepada petani pemilik dan penggarap lahan calon LP2B mengenai PLP2B melalui Dinas terkait dan penyuluh pertanian.

3. Memperkuat kelembagaan kelompok tani secara administratif dan juga secara keteknikan. Peningkatan kapasitas kepada petani melalui pelatihan, studi banding dan kerjasama dengan pihak swasta mengenai pertanian dari hulu hingga hilir.

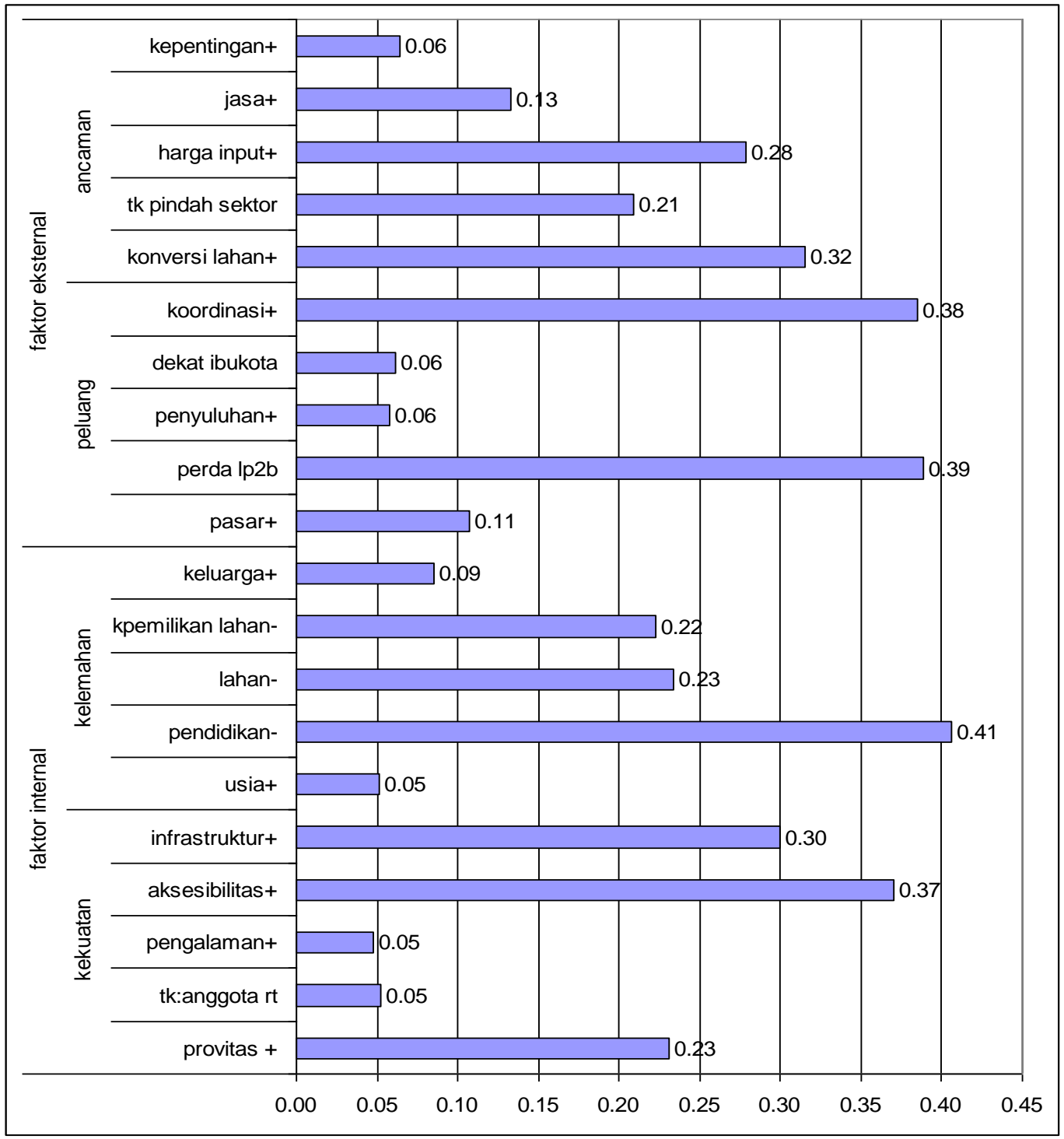

Gambar 4. Penentuan Strategi Prioritas Pengendalian Alih Fungsi Lahan di Kota Sukabumi 
Tabel 3. Pembobotan Komponen Dan Faktor-Faktor SWOT

\begin{tabular}{|c|c|c|c|c|c|}
\hline $\begin{array}{l}\text { Komponen } \\
\text { SWOT }\end{array}$ & $\begin{array}{l}\text { Prioritas } \\
\text { komponen }\end{array}$ & & Faktor-faktor SWOT & $\begin{array}{l}\text { Prioritas faktor } \\
\text { dalam } \\
\text { komponen }\end{array}$ & $\begin{array}{l}\text { Prioritas faktor } \\
\text { keseluruhan }\end{array}$ \\
\hline \multirow{5}{*}{ Kekuatan } & \multirow{5}{*}{0,07} & S1 & Produktivitas tanaman padi tinggi & 0,23 & 0,015 \\
\hline & & S2 & TK adalah anggota keluarga & 0,05 & 0,003 \\
\hline & & S3 & Pengalaman berusahatani lama & 0,05 & 0,003 \\
\hline & & S4 & Aksesibilitas mendukung sektor pertanian & 0,37 & 0,025 \\
\hline & & S5 & Infrastruktur Pertanian mendukung & 0,30 & 0,020 \\
\hline \multirow{5}{*}{ Kelema-han } & \multirow{5}{*}{0,22} & W1 & Petani berusia tua & 0,05 & 0,011 \\
\hline & & W2 & Pendidikan petani rendah & 0,41 & 0,090 \\
\hline & & W3 & Luas lahan garapan sempit & 0,23 & 0,052 \\
\hline & & W4 & Kepemilikan lahan dominan penggarap & 0,22 & 0,049 \\
\hline & & W5 & Jumlah anggota keluarga banyak & 0,09 & 0,019 \\
\hline \multirow{5}{*}{ Peluang } & \multirow{5}{*}{0,58} & $\mathrm{O} 1$ & Demand beras tinggi & 0,11 & 0,062 \\
\hline & & $\mathrm{O} 2$ & Perda LP2B sedang dalam penyusunan & 0,39 & 0,225 \\
\hline & & $\mathrm{O} 3$ & Frekuensi penyuluhan tinggi & 0,06 & 0,033 \\
\hline & & $\mathrm{O} 4$ & $\begin{array}{l}\text { Wilayah dekat dengan ibukota negara, } \\
\text { propinsi }\end{array}$ & 0,06 & 0,036 \\
\hline & & $\mathrm{O} 5$ & Koordinasi instansi terkait baik & 0,38 & 0,223 \\
\hline \multirow{5}{*}{ Ancaman } & \multirow{5}{*}{0,13} & $\mathrm{~T} 1$ & Konversi lahan tinggi & 0,32 & 0,042 \\
\hline & & $\mathrm{T} 2$ & Transformasi TK pertanian ke non-pertanian & 0,21 & 0,028 \\
\hline & & T3 & Harga input tinggi & 0,28 & 0,037 \\
\hline & & $\mathrm{T} 4$ & Pembangunan sektor jasa lebih maju & 0,13 & 0,018 \\
\hline & & T5 & Banyak kepentingan terkait lahan sawah & 0,06 & 0,008 \\
\hline
\end{tabular}

Tabel 4. Analisis SWOT dalam Penentuan Strategi Mengatasi Alih Fungsi Lahan

\begin{tabular}{|c|c|c|}
\hline INTERNAL & $\begin{array}{l}\text { Kekuatan (S): } \\
\text { - Produktivitas tanaman padi tinggi } \\
\text { - TK berasal dari anggota keluarga } \\
\text { - Pengalaman berusahatani lama } \\
\text { - Aksesibilitas mendukung } \\
\text { - Infrastruktur pertanian mendukung }\end{array}$ & $\begin{array}{l}\text { Kelemahan }(W) \text { : } \\
\text { - Petani berusia tua } \\
\text { - Pendidikan petani rendah } \\
\text { - Luas lahan garapan sempit } \\
\text { - Kepemilikan lahan banyak } \\
\text { penggarap } \\
\text { - Banyak anggota keluarga yang } \\
\text { ditanggung }\end{array}$ \\
\hline 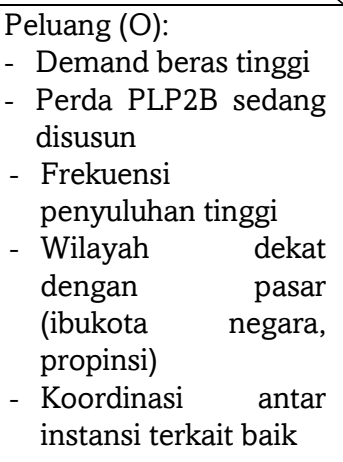 & $\begin{array}{l}\text { S-O Strategi } \\
\text { 1. Perlu adanya dukungan dari } \\
\text { pemerintah terkait dengan } \\
\text { peningkatan produktivitas dan } \\
\text { pengamanan harga(S1, S4, S5, } \\
\text { O1, O2, O5). N = 0,586 } \\
\text { 2. Sosialisasi kepada petani pemilik } \\
\text { dan penggarap lahan calon LP2B } \\
\text { (S2, S3, O2, O3, O5). } \mathrm{N}=0,487\end{array}$ & $\begin{array}{l}\text { W - O Strategi } \\
\text { 1. Sosialisasi kepada pemuda } \\
\text { untuk termotivasi berusaha di } \\
\text { sektor pertanian (W1,W2, W5, } \\
\text { O1, O3). } \mathrm{N}=0,215 \\
\text { 2. Penyusunan Kebijakan LP2B } \\
\text { (W3, W4, O2, O3, O5). } \\
\mathrm{N}=0,582\end{array}$ \\
\hline $\begin{array}{l}\text { Ancaman }(\mathrm{T}) \text { : } \\
\text { - } \text { Konversi lahan tinggi } \\
\text { - } \text { Transformasi TK } \\
\text { pertanian ke sektor } \\
\text { non-pertanian } \\
\text { - Harga input tinggi } \\
\text { - Sektor jasa lebih } \\
\text { maju dibanding } \\
\text { pertanian dengan } \\
\text { - Terkait dentingan }\end{array}$ & $\begin{array}{l}\mathrm{S} \text { - T Strategi } \\
\text { 1. Pengadaan bibit unggul yang } \\
\text { mudah didapat dan terjangkau } \\
\text { harganya (S1, S4, S5, T3) = SO1. } \\
\mathrm{N}=0,097\end{array}$ & $\begin{array}{l}\text { W - T Strategi } \\
\text { 1. Memperkuat kelembagaan } \\
\text { dalam kelompok tani secara } \\
\text { administratif dan juga secara } \\
\text { keteknikan (W1, W2, W5, T1, } \\
\text { T3). N=0,199 } \\
\text { 2. Membangun kerjasama antara } \\
\text { swasta dan kelompok tani } \\
\text { dalam mengelola sektor } \\
\text { pertanian. (W3, W4, T1, T2, } \\
\text { T3, T4). N=0,226 }\end{array}$ \\
\hline
\end{tabular}




\section{KESIMPULAN}

Berdasarkan hasil analisis dan pembahasan, serta kaitannya dengan tujuan penelitian maka disimpulkan hal-hal sebagai berikut: telah terjadi konversi lahan dari tahun 2010 hingga 2015 mencapai 181,94 ha. Strategi dalam mengatasi alih fungsi lahan di Kota Sukabumi adalah dengan memberikan insentif dan disinsentif yang sesuai, penguatan kelembagaan, peningkatan kapasitas sumberdaya manusia selaku pemangku kepentingan dan petani di lahan PLP2B dengan strategi utama sebagai berikut: Memberi dukungan yang terkait dengan peningkatan produktivitas baik kualitas dan kuantitasnya. Dukungan ini dapat dimasukkan dalam poin insentif dan disinsentif PLP2B, sosialisasi kepada petani pemilik dan penggarap lahan calon LP2B, membangun kerjasama antara swasta dan kelompok tani dalam mengelola sektor pertanian, sosialisasi kepada pemuda untuk termotivasi berusaha di sektor pertanian, memperkuat kelembagaan dalam kelompok tani secara administratif dan juga secara keteknikan. Peningkatan kapasitas kepada petani melalui pelatihan, studi banding dan kerjasama dengan pihak swasta mengenai pertanian dari hulu hingga hilir.

\section{DAFTAR PUSTAKA}

Katayama N., Baba YG., Kusumoto Y., Tanaka K. 2015. A Review of Post-War Changes in Rice Farming and Biodiversity in Japan. Volume 132, Pages 73-84. Agricultural Systems. Elsevier.

Khudori. 2012. Konversi Lahan Pertanian. Koran Sindo. $\underline{\text { http://www. }}$ unisosdem.org/article_detail.php?aid=1275\&coid=4\&caid=33\&gid=2.

Utomo, M, Eddy Rifai dan Abdulmutalib Thahir. 1992. Pembangunan dan Alih Fugsi Lahan. Universitas Lampung, Lampung.

Sumaryanto, Supena Friyatno, dan Bambang Irawan. 1994. Analisis Kebijaksanaan Konversi Lahan Sawah ke Penggunaan Non Pertanian. Pusat Penelitian dan Pengembangan Sosial Ekonomi Pertanian. Bogor.

Irawan, B. 2008. Meningkatkan Efektivitas Kebijakan Konversi Lahan. Forum Penelitian Agro Ekonomi. 26(2): 116-131.

Juanda B. 2009. Ekonometrika: Pemodelan dan Pendugaan. Bogor (ID): IPB Press.

Irawan, B. 2005. Konversi Lahan Sawah: Potensi Dampak, Pola Pemanfaatannya, dan Faktor Determinan. Forum Penelitian Agro Ekonomi. 23(1): 1-8.

Rahayu W, Riptanti EW. 2010. Analisis Efisiensi Ekonomi Penggunaan Faktor-Faktor Produksi pada Usahatani Kedelai di Kabupaten Sukoharjo. Caraka Tani XXV No.1.

Isgin T., Bilgic A., Forster DL., Batte MT. 2008. Using Count Data Models to Determine the Factors Affecting Farmer's Quantity Decisions of Precisions Farming Technology Adoption. Computer and Electonic in Agriculture. 62: 231-242.

Rahayu W, Riptanti EW. 2010. Analisis Efisiensi Ekonomi Penggunaan Faktor-Faktor Produksi pada Usahatani Kedelai di Kabupaten Sukoharjo. Caraka Tani XXV No.1.

Rustiadi, E., Saefulhakim, S, dan Panuju,D. 2011. Perencanaan dan Pengembangan Wilayah. Crestpent Press dan Yayasan Pustaka Obor Indonesia. Jakarta. 